\title{
Relationship between the onset of oestrus, the preovulatory surge in luteinizing hormone and ovulation following oestrous synchronization and superovulation of farmed red deer (Cervus elaphus)
}

\author{
G. W. Asher ${ }^{1}$, M. W. Fisher ${ }^{2}$, H. N. Jabbour ${ }^{1}$, J. F. Smith ${ }^{1}$, R. C. Mulley ${ }^{3}$, \\ C. J. Morrow ${ }^{1}$, F. A. Veldhuizen ${ }^{1}$ and M. Langridge ${ }^{1}$
}

'Ruakura Agricultural Centre, Ministry of Agriculture and Fisheries, Private Bag, Hamilton, New Zealand, ' Invermay Agricultural Centre, Ministry of Agriculture and Fisheries, Private Bag, Mosgiel, New Zealand; and ${ }^{3}$ University of Western Sydney, Richmond, NSW 2753, Australia

Summary. The timing of ovulation relative to the onset of oestrus and the preovulatory surge in luteinizing hormone (LH) was studied in red deer following treatments to synchronize oestrus and induce either a monovulatory or superovulatory response. Mature hinds ( $n=36$ ) were allocated randomly to two mating groups $(n=16+20)$, with respective treatments staggered by 4 weeks during the 1990 rut (March-April). Each hind was treated with an intravaginal controlled internal drug releasing (CIDR)type $\mathrm{S}$ device for 14 days. Treatments to induce a monovulatory response included CIDR device alone (treatment $\mathrm{A} ; n=4+8$ ) and additional injection of $200 \mathrm{iu}$ pregnant mares' serum gonadotrophin (PMSG) at device removal (treatment B; $n=4+4$ ). Treatments to induce a superovulatory response included injections of $200 \mathrm{iu}$ PMSG and 0.5 units ovine follicle-stimulating hormone (FSH) at about time of removal of CIDR devices (treatment $\mathrm{C} ; n=4+4$ ) and further treatment with gonadotrophinreleasing hormone (GnRH) analogue $18 \mathrm{~h}$ after removal of CIDR devices (treatment $\mathrm{D} ; n=4+4)$. The hinds were run with crayon-harnessed stags from insertion of CIDR devices (12 March or 9 April) and blood samples were taken every second day to determine plasma progesterone. Further blood samples were collected for determination of plasma $\mathrm{LH}$ and progesterone via indwelling jugular cannulae every $2 \mathrm{~h}$ for $72 \mathrm{~h}$ from removal of CIDR devices. Hinds were allocated randomly to an initial ovarian examination by laparoscopy at either 16 or $20 \mathrm{~h}$ ( $\mathrm{A}$ and $\mathrm{B}$ ), or 12 or $16 \mathrm{~h}$ (C and D) after the onset of oestrus, with laparoscopy repeated at intervals of $8 \mathrm{~h}$ until either ovulation was recorded (A and B), or for four successive occasions (C and D). All hinds received cloprostenol injections 15 days after device removal.

A total of 28 hinds $(78 \%)$ exhibited oestrus and a preovulatory $\mathrm{LH}$ surge, with mean ( \pm SEM) times to onset of oestrus of $44.6 \pm 1.0 \mathrm{~h}(\mathrm{~A} ; n=7), 37.4 \pm 2 \cdot 0 \mathrm{~h}(\mathrm{~B} ; n=$ $7), 16.3 \pm 1.7 \mathrm{~h}(\mathrm{C} ; n=6)$ or $14.0 \pm 1.7 \mathrm{~h}(\mathrm{D} ; n=8)$. Failure to exhibit oestrus or $\mathrm{LH}$ surge was most prevalent among hinds in treatment $\mathrm{A}$ early in the rut. For all treatments, the onset of oestrus occurred between $8 \mathrm{~h}$ before and $8 \mathrm{~h}$ after the $\mathrm{LH}$ peak and the mean ( \pm SEM) interval from onset of oestrus to (first) ovulation was $24 \cdot 7 \pm 1.0 \mathrm{~h}$, $20 \cdot 6 \pm 1 \cdot 0 \mathrm{~h}, 20 \cdot 0 \pm 2.9 \mathrm{~h}$ and $22 \cdot 0 \pm 3 \cdot 2 \mathrm{~h}$ for treatments $\mathrm{A}-\mathrm{D}$, respectively. Superovulation was characterized by nonsynchronous ovulations, with no apparent differences between treatments C and D. Initial ovarian examination showed that $4.5 \%$ of total (day 15 ) ovulations had occurred $12-16 \mathrm{~h}$ after oestrus, increasing progressively to $80.7 \%$ by $36-40 \mathrm{~h}$, indicating poor ovulation synchrony. The overall mean ovulation 
rate was $8 \cdot 8 \pm 1 \cdot 1$. Concentrations of progesterone during the luteal phase were correlated with ovulation rate. Administration of cloprostenol 15 days after removal of CIDR devices promoted luteal regression in all hinds, but return to oestrus occurred over seven days and two superovulated hinds retained multiple embryos to term despite treatment.

Keywords: red deer; oestrus; ovulation; luteinizing hormone; progesterone

\section{Introduction}

Artificial insemination and embryo transfer are powerful techniques for increasing rates of genetic gain in domestic livestock species. These reproductive manipulations have potential application in conservation of endangered mammalian species, either to prevent inbreeding of captive populations (e.g. artificial insemination) or to increase population size through interspecies surrogacy programmes (e.g. embryo transfer).

These techniques have been applied to farmed cervid species, including red deer (Asher et al., 1988a; Fennessy et al., 1989a, 1990a) and fallow deer (Dama dama; Asher et al., 1988b, 1990a; Jabbour et al., 1990) with variable degrees of success (Asher et al., 1991). The effectiveness of both artificial insemination and embryo transfer programmes depends on efficient techniques of oestrus and ovulation control, particularly in relation to synchronization of oestrus and ovulation and induction of a concise pattern of multiple ovulations. Most studies on red deer have involved the use of intravaginal controlled internal drug releasing (CIDR) devices (type $S$ or type $G$ ) together with strategically timed injections of exogenous gonadotrophins (pregnant mares' serum gonadotrophin (PMSG), follicle-stimulating hormone (FSH) or both) to control and synchronize follicular development and allow for fixed-time insemination (artificial insemination) or to synchronize ova development (embryo transfer), as reviewed by Asher et al. (1991). The efficacy of such treatments, in terms of induction and synchronization of oestrus or ovulation, has not been thoroughly evaluated for this species. To improve further the effectiveness of artificial insemination and embryo transfer of red deer, we attempted to determine the incidence and timing of ovulation relative to removal of CIDR devices, the onset of oestrus and the preovulatory luteinizing hormone (LH) surge, for the induction of a monovulatory response or a superovulatory response.

\section{Materials and Methods}

\section{Animals and management}

Thirty-six parous ( $3-10$ years old) red deer hinds at the Ruakura Agricultural Centre ( $\left.37^{\circ} 46^{\prime} \mathrm{S}, 175^{\circ} 20^{\prime} \mathrm{E}\right)$, with a mean ( \pm SEM) liveweight of $92 \cdot 3 \pm 3 \cdot 3 \mathrm{~kg}$, were allocated to two mating groups $(n=16$ and 20$)$ on 6 March 1990 . All had calved in the previous season (December 1989) and their offspring were weaned on 6 March. Each group of hinds was run continuously with a single fertile stag ( 4 years old) from the start of oestrous synchronization treatment (group 1 on 12 March; group 2 on 9 April) until at least 45 days later. The herd of deer was contained in high-fenced paddocks, grazed on ryegrass clover pastures and offered supplements of meadow hay.

\section{Synchronization and superovulation treatment}

Each of the hinds within the two trial groups was assigned to one of four treatments balanced for liveweight. Two treatments ( $A$ and $B$ ) were applied to induce monovulation and two (C and D) to induce superovulation. The synchronization treatment involved intravaginal insertion of CIDR devices (CIDR-type S, 0.3 g progesterone per device; Agricultural Division, CHH Plastic Products Group Ltd, Hamilton, NZ). Each hind received a single device for a total period of 14 days. This included device replacement on day 10. Hinds in treatment A $(n=4+8$; groups 1 and 2, respectively) each received CIDR devices only. Those in treatment $\mathbf{B}(n=4+4)$ also received an i.m. injection of 200 iu PMSG (Folligon: Intervet, Lane Cove, NSW, Australia) at withdrawal of the CIDR devices. Hinds in treatment $\mathrm{C}(n=4+4)$ each received 0.5 units ovine FSH (Ovagen: Immuno-Chemical Products Ltd, Auckland, NZ) and 200 iu PMSG. FSH was delivered as 8 equal-dose (0.06 units) i.m. injections at intervals of $12 \mathrm{~h}$ starting $72 \mathrm{~h}$ 
before withdrawal of the CIDR devices. PMSG was delivered as a single i.m. injection $72 \mathrm{~h}$ before withdrawal of the CIDR devices. Hinds in treatment $\mathrm{D}(n=4+4)$ each received the same treatment protocol as for treatment $\mathrm{C}$ but also received an i.v. injection of synthetic GnRH ( $500 \mu \mathrm{g}$ gonadorelin; Fertagyl: Intervet, Lane Cove, NSW, Australia) I $8 \mathrm{~h}$ after withdrawal of the CIDR devices.

\section{Prostaglandin treatment}

An i.m. injection of $500 \mu \mathrm{g}$ cloprostenol ( $2 \mathrm{ml}$ Estrumate: Imperial Chemical Industries plc, Cheshire, UK) was administered to each hind 15 days after withdrawal of the CIDR devices. This was administered primarily to prevent implantation of multiple embryos and to resynchronize matings.

\section{Detection of oestrus}

Each of the stags was fitted with a ram mating harness (Guinness et al., 1971; Asher, 1985) for 5 days from withdrawal of the CIDR devices. Observations for crayon mating marks were conducted at least every $2 \mathrm{~h}$ during the $72 \mathrm{~h}$ after device withdrawal, by close inspection of each hind at blood sampling. Crayons were replaced at least once every $12 \mathrm{~h}$ during this period. Harnesses were fitted again for 7 days from prostaglandin administration, 15 days after removal of the CIDR devices. Inspection for mating marks was conducted once a day during this period.

\section{Collection of blood samples}

All hinds were mustered into a covered handling shed, individually restrained in a pneumatically-controlled cradle and blood samples were taken by jugular venepuncture $(10 \mathrm{ml}$ heparinized vacutainers) every 2 days from 6 days before insertion of CIDR devices until 30 days after removal of the devices. Additional samples were collected $6 \mathrm{~h}$ after insertion and removal of the CIDR devices. Futhermore, blood samples were taken from all hinds every $2 \mathrm{~h}$ for $72 \mathrm{~h}$ after removal of the CIDR devices, from the right external jugular vein via indwelling catheters (Intracath 3122 : Deseret Company, Sandy, UT, USA) inserted 6-8 $\mathrm{h}$ before the start of sampling. Restraint was not necessary for these samplings, and blood was withdrawn while groups of hinds stood quietly in $2.4 \mathrm{~m}^{2}$ pens following repeated mustering from nearby pastures.

Blood samples were centrifuged at $1000 \mathrm{~g}$ for $25 \mathrm{~min}$ immediately after collection and the plasma aliquots stored at $-10^{\circ} \mathrm{C}$ until assayed.

\section{Assessment of time of ovulation}

Hinds within each treatment were allocated randomly for initial ovarian examination by laparoscopy at 16 or $20 \mathrm{~h}$ after the onset of oestrus for treatments A and B (monovulation) and 12 or $16 \mathrm{~h}$ after the onset of oestrus for treatments $\mathrm{C}$ and $\mathrm{D}$ (superovulation). Ovarian examinations were repeated at intervals of $8 \mathrm{~h}$ until an ovulation had been recorded for hinds in treatments $\mathrm{A}$ and $\mathrm{B}$. For hinds in treatment $\mathrm{C}$ and $\mathrm{D}$, four repeat laparoscopic examinations were performed. Ovulation was deemed to have occurred at the mid-point (i.e. $4 \mathrm{~h}$ ) between two consecutive observations. Hinds not detected in oestrus were examined laparoscopically $72 \mathrm{~h}$ after removal of the CIDR device.

Laparoscopy was performed while the hinds were anaesthetized with an i.m. injection of $1.0-2.0 \mathrm{mg}$ xylazine hydrochloride (Rompun: Bayer Leverkusen, Germany) $\mathrm{kg}^{-1}$ liveweight. External puncture wounds were treated with topical antibiotic powder (Aureomycin: Cyanamid NZ Ltd, Auckland, NZ) following laparoscopy and $10 \mathrm{ml}$ of a long-acting antibiotic preparation (Propen LA: Glaxo NZ Ltd, Auckland, NZ) was administered by i.m. injection every $48 \mathrm{~h}$ from cannulation until cessation of laparoscopy. Anaesthesia was reversed with an i.v. injection of $0.5 \mathrm{mg}$ yohimbine hydrochloride (Recervyl: Aspiring Animal Services, Wanaka, NZ) kg ' liveweight.

\section{Assessment of final ovulation rate}

All hinds were again examined laparoscopically 15 days after withdrawal of the CIDR devices and the total numbers of corpora lutea were recorded.

\section{Hormone assays}

Concentrations of progesterone were measured in plasma in duplicate by direct radioimmunoassay as described for red deer by Asher (1990). Serial dilutions of pooled plasma samples with high concentrations of immunoreactive progesterone gave inhibition curves parallel to those generated for progesterone in buffer. All of the samples from an individual hind were included within a single assay. Samples with low, medium and high concentrations of progesterone were included as control samples at frequent intervals in each assay. The interassay coefficients of variation were $15.7 \%$ for the low control (mean $0.59 \mathrm{ng} \mathrm{ml}$ '), $12.4 \%$ for the medium control ( $5.58 \mathrm{ng} \mathrm{m}^{-1}$ ) and $10.6 \%$ for the high control $\left(11.40 \mathrm{ng} \mathrm{ml}^{-1}\right)$ samples, respectively. The intra-assay coefficients of variation were $10 \cdot 3,8.2$ and $6 \cdot 2 \%$ for the 
three control samples, respectively. Sensitivity of the standard curve, defined as the first point that was significantly different from 0 , was $0 \cdot 10 \mathrm{ng} \mathrm{ml}^{-1}$.

Plasma LH concentrations were determined in duplicate by heterologous radioimmunoassay described for sheep plasma by Scaramuzzi et al. (1970) and validated previously for fallow deer plasma (Asher et al., 1986) and red deer plasma (Kelly et al., 1982). The ovine pituitary LH preparation used for standards and iodinated tracer was NIH-LHSII (National Hormone and Pituitary Programme, University of Maryland, USA). The LH antibody, which had been raised in a rabbit also using NIH-LH-S1I as the antigen, was used in the assay at a final dilution of 1:200 000 . Crossreactivities with other proteins have been described previously (Kelly et al., 1982; Asher et al., 1986). Serial dilutions of pooled plasma samples from preovulatory hinds with high concentrations of immunoreactive LH gave inhibition curves parallel to those generated for NIH-LH-SI l in buffer. All samples were included in a single assay, although samples registering beyond the upper limit of the standard curve were re-assayed following serial dilution in red deer plasma containing low concentrations of immunoreactive LH. The interassay coefficient of variation for multiple determination of a cervine control sample (mean $5.3 \mathrm{ng} \mathrm{ml}^{-1}$ ) was $17.7 \%$. The intra-assay coefficient of variation was $8.0 \%$ and the sensitivity of the standard curve was $0.03 \mathrm{ng} \mathrm{NIH-LH}-\mathrm{S} 11\left(0.30 \mathrm{ng} \mathrm{m}^{-1}\right)$.

\section{Statistical analyses}

Data are expressed as a mean \pm SEM and were evaluated by analysis of variance.

\section{Results}

\section{Incidence of oestrus and ovulation}

Of the 36 hinds in the trial, 31 (86\%) exhibited oestrus, with 30 ovulating subsequently (Table 1 ) (one hind was killed by the stag after the onset of oestrus and preovulatory LH surge but before the scheduling of the first ovarian examination). All but two of these hinds exhibited a distinct preovulatory LH surge during the period of intensive blood sampling. The remaining two oestrous or ovulatory hinds (treatment C) showed evidence of having exhibited their preovulatory LH surge at about the time of removal of the CIDR device.

Each of the five hinds not detected in oestrus after removal of the CIDR device was also found to be anovulatory, having failed to exhibit a preovulatory LH surge during the period of intensive blood sampling and showing no evidence of ovulation at laparoscopy. Anoestrous or anovulatory hinds occurred only among treatments $\mathrm{A}(n=4)$ and $\mathrm{B}(n=1)$.

The oestrous or ovulatory hinds in treatment $\mathrm{A}$ all had single ovulations, and only one hind in treatment B exhibited a double ovulation following administration of PMSG. By contrast, all hinds in treatments $\mathrm{C}$ and $\mathrm{D}$ exhibited multiple ovulations in response to PMSG plus FSH treatment, with final ovulation rates ranging from 2 to 16 .

\section{Plasma progesterone profiles}

Insertion of CIDR devices produced an average increase in plasma progesterone concentrations of about $3 \mathrm{ng} \mathrm{ml}^{\cdots 1}$ within $6 \mathrm{~h}$ for hinds in groups 1 and 2 . However, mean concentrations of progesterone at final withdrawal of CIDR devices were $<2 \mathrm{ng} \mathrm{ml}^{-1}$. Luteal development was manifest by increasing mean plasma progesterone concentrations for the 15 days following removal of CIDR devices. Concentrations of progesterone in plasma 15 days after removal of CIDR devices for monovulating hinds were about $2 \mathrm{ng} \mathrm{ml}^{-1}$. However, concentrations were positively correlated with ovulation rate, such that mean concentrations in excess of $10 \mathrm{ng} \mathrm{ml}^{-1}$ were observed for hinds with more than 6 corpora lutea. Hinds failing to ovulate exhibited low plasma progesterone concentrations ( $<1.0 \mathrm{ng} \mathrm{ml}^{-1}$ ) during this period (Fig. 1).

Administration of cloprostenol resulted in breakdown of corpora lutea, leading to a decline in mean plasma progesterone concentrations within $48 \mathrm{~h}$. Subsequent increasing mean concentrations indicate ovulation and luteal development. Oestrus was observed over 7 days from administration of cloprostenol, with the greatest incidence of oestrus occurring between 48 and $72 \mathrm{~h}$. 


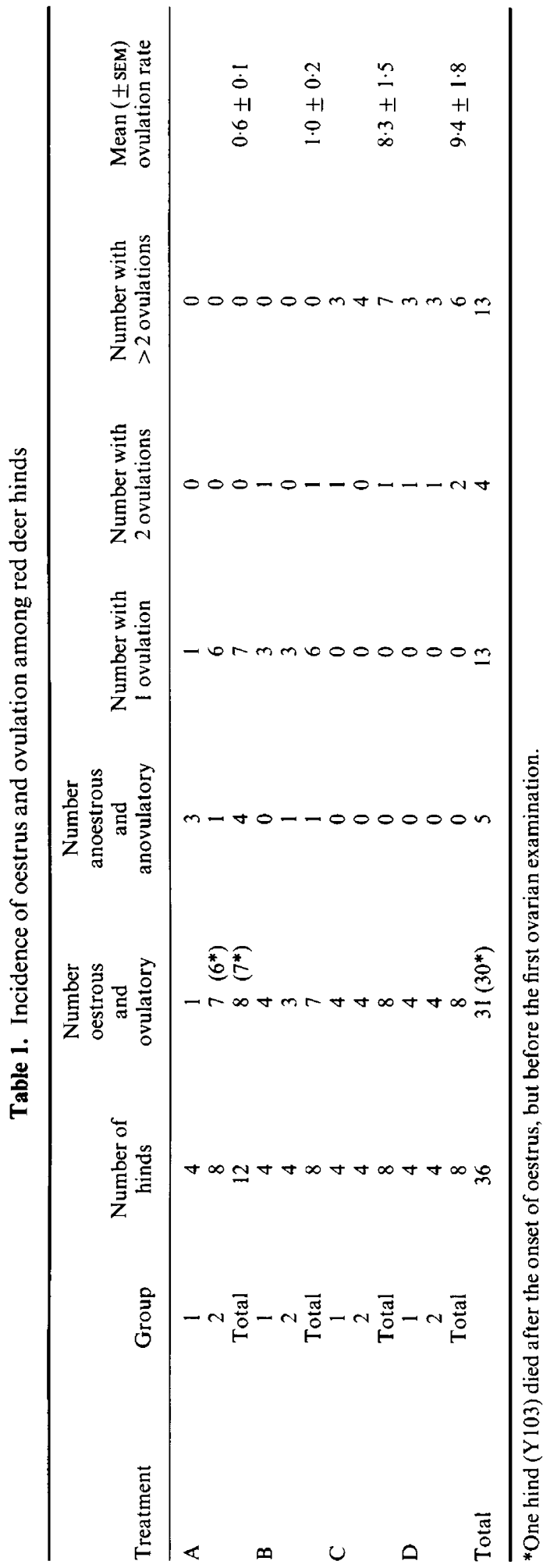




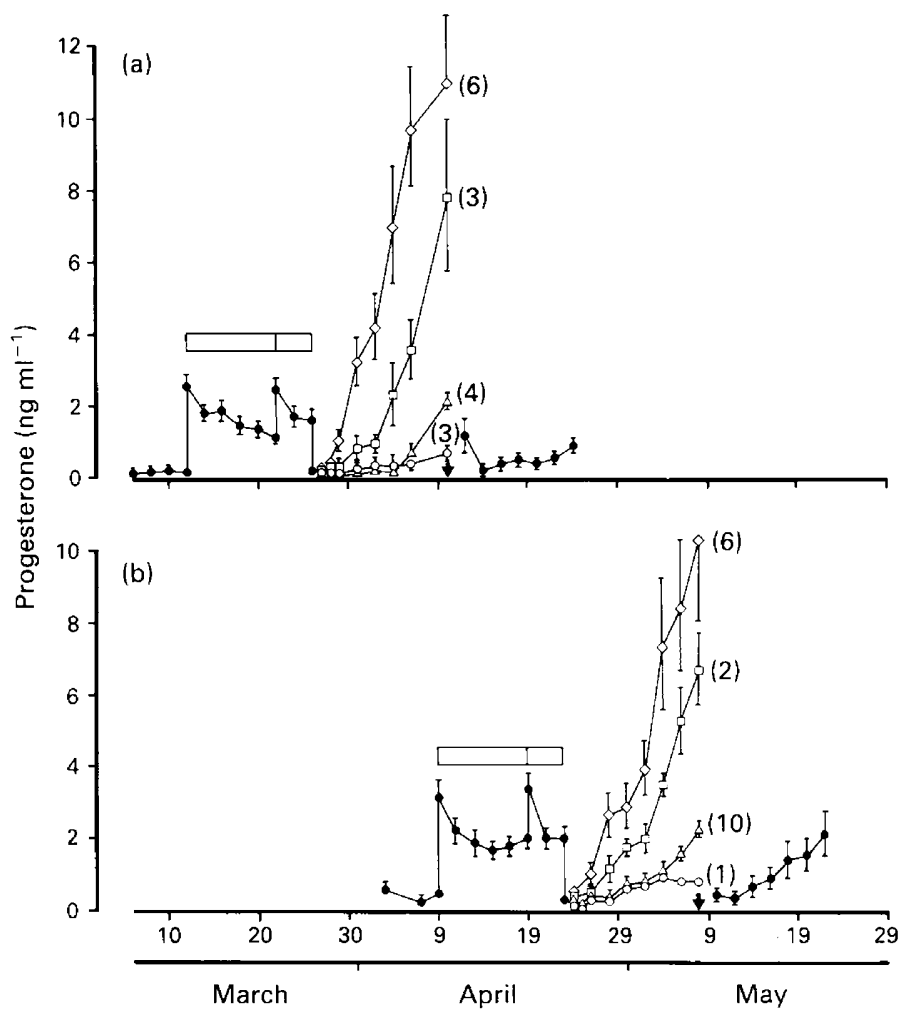

Fig. 1. Profiles of mean ( \pm SEM) concentrations of plasma progesterone for red deer hinds in (a) group 1 and (b) group 2 for 50 days from insertion of CIDR devices to 12 days after administration of prostaglandin $(\downarrow)$. Solid symbols indicate pooled data from all hinds. Mean values during luteal development are presented in relation to numbers of corpora lutea present, as follows: $(\bigcirc)$ no corpus luteum; $(\triangle)$ l corpus luteum; $(\square) 2-5$ corpora lutea and $(\diamond)>6$ corpora lutea. The number of hinds for each category is indicated next to each profile and the horizontal bar indicates the period of insertion of CIDR devices.

\section{Plasma progesterone and LH profiles around oestrus}

For hinds in treatments $\mathrm{A}$ and $\mathrm{B}$ (monovulation), mean plasma progesterone concentrations declined from about $1.8 \mathrm{ng} \mathrm{ml}^{-1}$ at removal of CIDR devices to $<0.2 \mathrm{ng} \mathrm{ml}^{-1}$ within $12 \mathrm{~h}$, although occasional erratic fluctuations occurred later in some hinds (Fig. $2 \mathrm{a}, \mathrm{b}$ ). This resulted in a general increase in mean plasma progesterone concentrations of up to $0.7 \mathrm{ng} \mathrm{ml}^{-1}$ between 12 and $24 \mathrm{~h}$ after removal of CIDR devices. The preovulatory LH surge, occurring over $12-14 \mathrm{~h}$ at mean times of $45 \mathrm{~h}(\mathrm{~A})$ or $38 \mathrm{~h}$ (B) after device removal, attained mean peak values $>70 \mathrm{ng} \mathrm{ml}^{-1}$ and was associated with mean plasma progesterone concentrations of $<0.4 \mathrm{ng} \mathrm{ml}^{-1}$. This represented about 50 -fold increase over previous basal values. The occurrence of the onset of oestrus varied in relation to the preovulatory LH surge, ranging from $8 \mathrm{~h}$ before to $4 \mathrm{~h}$ after peak LH concentrations (Fig. $2 \mathrm{a}, \mathrm{b})$. Hinds that failed to exhibit oestrus and to ovulate in treatments $\mathrm{A}(n=4)$ and $\mathrm{B}(n=1)$ did not exhibit preovulatory LH surges.

Mean plasma progesterone concentrations following removal of CIDR devices for hinds in treatments C and D (superovulation) were similar to those observed for monovulating hinds, although the subsequent profiles about the LH peak tended to be more erratic (Fig. 2c, d). The preovulatory $\mathrm{LH}$ surges of hinds receiving superovulation treatments were generally initiated within $24 \mathrm{~h}$ of the removal of CIDR devices (Table 2), resulting in erratic mean profiles normalized about device removal. When normalized about peak LH values, the mean profiles of the preovulatory 


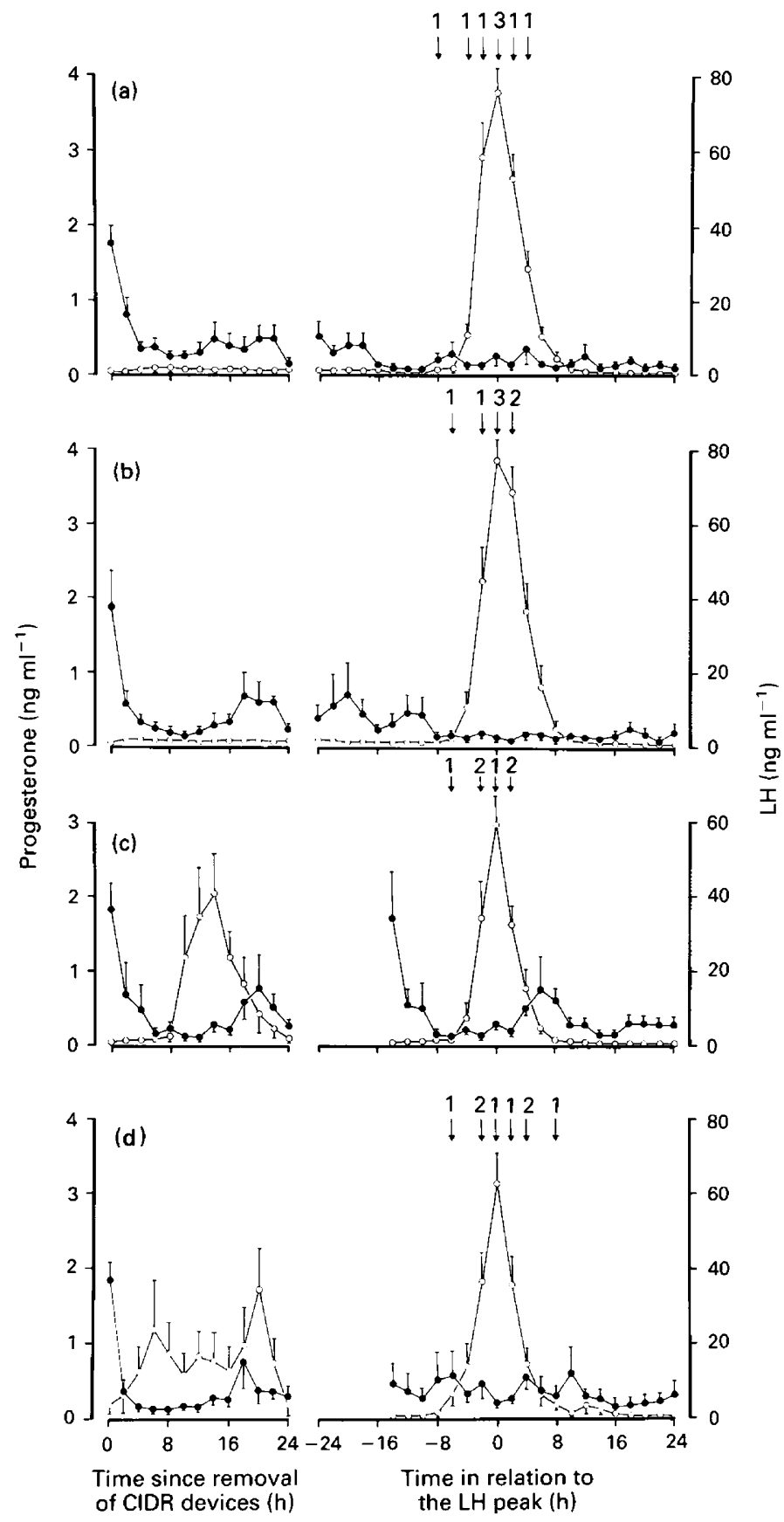

Fig. 2. Profiles of mean $( \pm$ SEM) concentrations of $(O)$ plasma progesterone and $(O) \mathrm{LH}$ for red deer hinds from samples collected at intervals of $2 \mathrm{~h}$ for $72 \mathrm{~h}$ after removal of CIDR devices, for individuals exhibiting oestrus and a preovulatory LH surge. The data are normalized from removal of CIDR devices and about the $\mathrm{LH}$ peak. Arrows indicate the onset of oestrus relative to the LH peak for individual hinds: (a) treatment $\mathrm{A}(n=8)$; (b) treatment $\mathrm{B}(n=7)$; (c) treatment $\mathrm{C}(n=6)$; and (d) treatment $\mathrm{D}(n=8)$. 
LH surges were similar to those of hinds in treatments A and B. The onset of oestrus of hinds in treatments $\mathrm{C}$ and $\mathrm{D}$ occurred between $6 \mathrm{~h}$ before and $8 \mathrm{~h}$ after peak LH concentrations (Fig. 2c, d).

Table 2. Mean ( \pm SEM) times (h) to oestrus, the luteinizing hormone peak and ovulation from removal of controlled internal drug releasing (CIDR) devices and the mean $\left( \pm\right.$ SEM) intervals between events ${ }^{a}$

\begin{tabular}{|c|c|c|c|c|c|c|}
\hline Treatment & $n$ & $\begin{array}{l}\text { Time to } \\
\text { onset of } \\
\text { oestrus }\end{array}$ & $\begin{array}{l}\text { Time to } \\
\text { LH peak }\end{array}$ & $\begin{array}{l}\text { Time to } \\
\text { (first) } \\
\text { ovulation }\end{array}$ & $\begin{array}{l}\text { Interval from } \\
\text { oestrus to (first) } \\
\text { ovulation }\end{array}$ & $\begin{array}{l}\text { Interval from } \\
\text { LH peak to } \\
\text { (first) ovulation }\end{array}$ \\
\hline $\begin{array}{l}\text { A: CIDR device } \\
\text { alone }\end{array}$ & 7 & $44 \cdot 6 \pm 1 \cdot 0$ & $45 \cdot 1 \pm 1 \cdot 3$ & $69 \cdot 3 \pm 1 \cdot 2$ & $24 \cdot 7 \pm 1 \cdot 0$ & $24 \cdot 1 \pm 1 \cdot 6$ \\
\hline $\begin{array}{ll}\text { B: } & \text { CIDR device } \\
& +200 \text { iu PMSG }\end{array}$ & 7 & $37 \cdot 4 \pm 2 \cdot 0$ & $38 \cdot 3 \pm 2 \cdot 3$ & $58 \cdot 0 \pm 2 \cdot 4$ & $20 \cdot 6 \pm 1 \cdot 0$ & $20 \cdot 0 \pm 1 \cdot 4$ \\
\hline $\begin{aligned} \mathrm{C}: & \mathrm{CIDR}+\mathrm{PMSG} \\
& +\mathrm{FSH}\end{aligned}$ & 6 & $16 \cdot 3 \pm 1 \cdot 7$ & $14 \cdot 0 \pm 0 \cdot 9$ & $36 \cdot 3 \pm 3 \cdot 1$ & $20 \cdot 0 \pm 2 \cdot 9$ & $22 \cdot 3 \pm 3 \cdot 6$ \\
\hline $\begin{aligned} \mathrm{D}: & \mathrm{CIDR}+\mathrm{PMSG} \\
& +\mathrm{FSH}+\mathrm{GnRH}\end{aligned}$ & 8 & $14 \cdot 0 \pm 1 \cdot 7$ & $13 \cdot 0 \pm 2 \cdot 1$ & $36 \cdot 0 \pm 3 \cdot 4$ & $22 \cdot 0 \pm 3 \cdot 2$ & $23 \cdot 0 \pm 3 \cdot 6$ \\
\hline
\end{tabular}

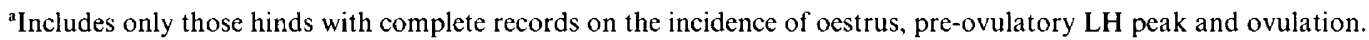
PMSG: pregnant mares' serum gonadotrophin; FSH: follicle-stimulating hormone; GnRH: gonadotrophin-releasing hormone.

Two hinds in treatment $\mathrm{C}$ did not appear to exhibit pronounced preovulatory LH surges. However, both showed evidence of having exhibited a premature LH surge before removal of the CIDR devices. In both cases, plasma LH concentrations were high (14.3 and $5.8 \mathrm{ng} \mathrm{ml}^{-1}$, respectively) at device withdrawal and declined subsequently to basal values $\left(<1.0 \mathrm{ng} \mathrm{ml}^{-1}\right)$. Both hinds exhibited oestrus within $10 \mathrm{~h}$, and ovulated within $30 \mathrm{~h}$ of removal of CIDR devices.

Administration of GnRH to treatment $\mathrm{D}$ hinds $18 \mathrm{~h}$ after removal of CIDR devices was associated with a transient increase in plasma LH concentrations. In most cases, this was manifest as a secondary, lower amplitude LH surge following the endogenous preovulatory LH surge. In one instance, GnRH injection either coincided with the preovulatory LH surge or precipitated the onset of the surge.

\section{Relationship between progesterone withdrawal, the onset of oestrus and ovulation}

For hinds in treatments $\mathrm{A}$ and $\mathrm{B}$ (monovulation), times to oestrus, the $\mathrm{LH}$ peak and ovulation were all advanced significantly $(P<0.05)$ by PMSG treatment at removal of the CIDR devices (Table 2). Furthermore, the mean intervals between oestrus, or the LH peak, and ovulation were reduced significantly $(P<0.05)$ from about $24 \mathrm{~h}$ to about $20 \mathrm{~h}$ by PMSG treatment. However, for most parameters the variance was marginally reduced for treatment $A$.

Hinds in treatments $\mathrm{C}$ and $\mathrm{D}$ (superovulation) exhibited oestrus significantly $(P<0.01)$ earlier than hinds in treatments $\mathrm{A}$ and $\mathrm{B}$ (monovulation). This was further reflected in the mean time to the LH peak and first ovulation. However, the mean intervals between these events were not significantly different from treatment $\mathrm{A}$ and $\mathrm{B}$ hinds $(P>0.01)$, although the variance was greatly increased $(P<0.05)$. There were no significant differences for any mean parameters between treatment $\mathrm{C}$ and $\mathrm{D}$ hinds, including final ovulation rate (Table 1 ).

Repeated laparoscopic examination of hinds in treatments C and D (superovulation), starting $12-16 \mathrm{~h}$ after the onset of oestrus, revealed increasing numbers of ovulated follicles over $24 \mathrm{~h}$ (Table 3). The trend in progressive ovulation incidence was essentially similar between treatments $\mathrm{C}$ and $\mathrm{D}$. For both treatments, initial examination revealed an ovulation rate of only $0.4(4.5 \%$ of total ovulations). However, the ovulation rate $24 \mathrm{~h}$ later was $7 \cdot 4(89.2 \%)$ and $6.9(73.4 \%)$ for the two treatments, respectively (Table 3). 
Table 3. Mean ( \pm SEM) ovulation rate and percentage of total (day 15) ovulations recorded at each successive laparoscopic examination after oestrus for superovulated red deer hinds in treatments C and D

\begin{tabular}{lccccc}
\hline & \multicolumn{5}{c}{ Laparoscopic examination (time from onset of oestrus) } \\
\cline { 2 - 6 } Treatment & 1 & 2 & 3 & 4 & 5 \\
& $(12-16 \mathrm{~h})$ & $(20-24 \mathrm{~h})$ & $(28-32 \mathrm{~h})$ & $(36-40 \mathrm{~h})$ & $($ day 15$)$ \\
\hline $\mathrm{C}$ & $0 \cdot 4 \pm 0 \cdot 4$ & $2 \cdot 5 \pm 0 \cdot 9$ & $5 \cdot 0 \pm 1 \cdot 5$ & $7 \cdot 4 \pm 1 \cdot 1$ & $8 \cdot 3 \pm 1 \cdot 5$ \\
& $(4 \cdot 8 \%)$ & $(30 \cdot 1 \%)$ & $(60 \cdot 2 \%)$ & $(89 \cdot 2 \%)$ & $(100 \%)$ \\
D & $0 \cdot 4 \pm 0 \cdot 3$ & $4 \cdot 6 \pm 1 \cdot 8$ & $5 \cdot 0 \pm 1 \cdot 8$ & $6 \cdot 9 \pm 1 \cdot 5$ & $9 \cdot 4 \pm 1 \cdot 8$ \\
& $(4 \cdot 3 \%)$ & $(48 \cdot 9 \%)$ & $(53 \cdot 2 \%)$ & $(73 \cdot 4 \%)$ & $(100 \%)$ \\
Total & $0 \cdot 4 \pm 0 \cdot 2$ & $3 \cdot 6 \pm 1 \cdot 0$ & $5 \cdot 0 \pm 1 \cdot 1$ & $7 \cdot 1 \pm 0.9$ & $8 \cdot 8 \pm 1 \cdot 1$ \\
& $(4 \cdot 5 \%)$ & $(40 \cdot 9 \%)$ & $(56 \cdot 8 \%)$ & $(80 \cdot 7 \%)$ & $(100 \%)$ \\
\hline
\end{tabular}

\section{Discussion}

This study is one of the first attempts to describe the relationships between oestrus, the preovulatory LH surge and ovulation in red deer, a species becoming increasingly popular as domestic livestock. The average intervals between withdrawal of exogenous progesterone and the onset of oestrus $(44.6 \mathrm{~h})$, and between oestrus and ovulation $(24.7 \mathrm{~h})$ for hinds undergoing oestrous synchronization treatment with intravaginal CIDR devices alone (i.e. without exogenous gonadotrophin support) are similar to those described previously for farmed fallow deer treated with CIDR devices or prostaglandin injections (Asher et al., 1990b). However, the additional administration of $200 \mathrm{iu}$ PMSG in red deer hinds at the time of removal of CIDR devices resulted in a significant advancement of $7.2 \mathrm{~h}$ in the mean time to onset of oestrus to $37.4 \mathrm{~h}$ and a $4 \cdot 1 \mathrm{~h}$ decrease in the average interval between oestrus and ovulation to $20.6 \mathrm{~h}$. There was no apparent difference in the mean amplitude or duration of the preovulatory LH surge of hinds that did or did not receive PMSG.

Oestrous synchronization of red deer hinds for purposes of artificial insemination has routinely involved the administration of 150-250 iu PMSG at or near removal of CIDR devices (Asher et al., 1991). PMSG is perhaps necessary to induce oestrus and ovulation before the onset of the normal breeding season, to offset the inhibitory effects of handling stress on ovulation, and to promote ovulation synchrony in groups of hinds (Fennessy et al., 1989b). This study indicated that CIDR device treatment alone just before the natural rut in early April is associated with a high level of oestrous and ovulatory failure, in that three of four (75\%) hinds treated in late March failed to respond, whereas all four hinds receiving PMSG during the same period exhibited oestrous and ovulatory responses. This is supported by earlier studies on the efficacy of CIDR devices and PMSG in inducing ovulation in red deer hinds before the natural breeding season (Fisher et al., 1986, 1989). The putative stress effects on oestrus and ovulation have not been demonstrated conclusively for red deer, although it is known that the adrenal glands may secrete physiologically sufficient quantities of progesterone in response to stress in both red deer (Jopson et al., 1990) and fallow deer (Asher et al., 1989) to inhibit LH secretion during the preovulatory period (Asher et al., 1986). PMSG administration may overcome this effect. Furthermore, the effects of PMSG on oestrus and ovulation synchrony in red deer require further investigation. While administration of PMSG at removal of CIDR devices reduced the mean interval to onset of oestrus and ovulation, this was not associated with reduced variance. In fact, within the limitation of small sample sizes, PMSG appeared to increase the variance. PMSG, even at such low dose rates, increases the incidence of multiple ovulation and multiple births (Fisher et al., 1986, 1989; Asher et al., 1988a; Fennessy et al., 1990b). In fallow deer, this has proved counter-productive in artificial insemination programmes (Asher et al., 1991; Jabbour et al., 1991), although there is little evidence of major 
production losses through reduced fertility, increased embryonic loss and increased perinatal mortality in red deer (Fennessy et al., 1990b). Thus, the routine use of PMSG for oestrous synchronization in red deer may need further evaluation for artificial insemination programmes conducted within the natural breeding season.

A number of studies on fallow deer have demonstrated a relationship between oestrus and $\mathrm{LH}$ secretion, whereby the onset of oestrus coincides with the onset of the preovulatory $\mathrm{LH}$ surge, which attains its peak 4-6 h later (Asher et al., 1986, 1990b; Asher \& Thompson, 1989). This is also the case for sheep (Quirke et al., 1981; Robinson et al., 1987). However, such a relationship was not apparent in the present study on red deer. In fact, the recorded onset of oestrus in treatment $\mathrm{A}$ and $\mathrm{B}$ hinds occurred from $8 \mathrm{~h}$ before to $4 \mathrm{~h}$ after the peak of the preovulatory LH surge. The onset of oestrus in red deer is therefore not a reliable predictor of the occurrence of the preovulatory LH surge. The reasons for the less precise relationship are not apparent. It may be that for red deer, the threshold levels of follicular oestrogen and androgen secretion required for the initiation of oestrus differ from those required to stimulate the $\mathrm{LH}$ surge. However, further considerations include the effectiveness of oestrous detection in the study and the possibility of failure of the stag to immediately exhibit mounting responses to oestrous hinds.

Retrospective analysis of the interval between the LH peak and ovulation indicate a more variable relationship than that occurring between the onset of oestrus and ovulation. Although these data are not statistically significant, they do conflict with those observed for sheep where there is a remarkable constancy in the interval from the preovulatory LH surge to ovulation (Cumming et al., 1973). This may, however, reflect less precision in measuring the actual timing of follicular rupture $( \pm 4 \mathrm{~h})$ in red deer hinds. In general, the interval from the LH peak to ovulation is similar, if not a little shorter, than that occurring in sheep (Cumming et al., 1973), cattle (Henricks et al., 1970; Schams et al., 1977) and goats (Mori \& Kano, 1984).

Superovulation treatments (C and D) used in this study successfully induced multiple ovulations in red deer hinds, although the response was highly variable in terms of total ovulations recorded 15 days after removal of CIDR devices. Such variability in ovarian response is a common feature of induced multiple ovulation of red deer (Fennessy et al., 1990a). In comparison to oestrous synchronization (induction of monovulation) treatments, induction of multiple ovulations was associated with a marked degree of advancement in the onset of oestrus and the preovulatory $\mathrm{LH}$ surge relative to withdrawal of progesterone. This has also been observed for superovulated sheep following synchronization with CIDR devices (Thompson et al., 1990). Furthermore, a number of studies have indicated a marked relationship between the time of oestrous onset and ovulatory status of ewes treated with progestagen sponges (Robinson et al., 1987) or CIDR devices (Thompson \& Smith, 1988; Thompson et al., 1990). For both red deer and sheep this presumably indicates the influence of multiple recruited follicles, whereby cumulative secretion of follicular steroids results in the earlier attainment of threshold concentrations required for overt oestrus and initiation of the LH surge. Furthermore, the plasma LH profiles of two hinds in treatment $\mathrm{C}$ indicate that the preovulatory LH surge may have occurred in the period immediately before removal of CIDR devices. The concentrations of circulating progesterone attained from these devices may occasionally not be sufficient to exert a suppressive or regulatory effect on follicular development in red deer hinds; although in this trial, the devices were replaced 4 days before final withdrawal to increase plasma progesterone concentrations over the follicular recruitment period. In both cases observed, the onset of oestrus was recorded within $10 \mathrm{~h}$ of removal of the CIDR devices. Observations to detect oestrus were not performed before device removal; it is therefore not known whether these hinds were oestrous during the latter stages of CIDR device insertion.

The relationship between the onset of oestrus and the preovulatory LH surge was similar for both superovulating and monovulating hinds, with oestrus occurring from between $8 \mathrm{~h}$ before and $8 \mathrm{~h}$ after the LH peak. However, superovulating hinds clearly exhibited more variation in the interval 
from the onset of oestrus and LH peak to first ovulation. The data from this study indicate that hinds treated with PMSG and ovine FSH exhibited nonsynchronous ovulations, with individual ovulations recorded as occurring over $24 \mathrm{~h}$. The disparity between the total ovulation rates recorded by about $60 \mathrm{~h}$ after withdrawal of progesterone and 2 weeks later clearly demonstrate that further ovulations may have occurred during the luteal phase, a phenomenon that has been observed in superovulated sheep (Hunter \& Southee, 1989). There is little doubt that for embryo transfer programmes poor ovulation synchrony in donors would be counterproductive because of reduced fertilization rates and recovery of ova at different (and inappropriate) stages of embryonic development (Walker et al., 1986). It would, therefore, be advantageous to induce a greater degree of ovulation synchrony. We investigated the effects of GnRH injection $18 \mathrm{~h}$ after withdrawal of CIDR devices on ovulation synchrony, on the basis that increasing the preovulatory LH surge may promote ovulation synchrony (Nancarrow et al., 1984; Walker et al., 1986, 1987), but there was no apparent effect of treatment. Ovulations in treatment D hinds were clearly nonsynchronous, contrasting with studies on ewes in which $80 \%$ of ovulations following GnRH treatment occurred within $3 \mathrm{~h}$ (Walker et al., 1987). In most cases, the GnRH injection occurred after the preovulatory LH surge and failed to elicit a significant $\mathbf{L H}$ response. In only one case did the two events occur simultaneously, but this particular hind failed to exhibit a good superovulatory response (i.e. two ovulations). It may have been more appropriate to administer GnRH at about $12 \mathrm{~h}$ after removal of CIDR devices, closer to the actual timing of the initiation of the preovulatory LH surge. Given that poor ovulation synchrony in donors is a potential problem for embryo transfer in red deer, further studies may need to evaluate further other mechanisms for improving synchrony, including control of follicular wave patterns during progesterone treatment and immunoneutralization of PMSG after withdrawal of progesterone.

The relationship between the number of corpora lutea and plasma progesterone concentrations during the luteal phase is in agreement with the studies of Kelly et al. (1982) and provides further evidence that luteal tissue is the principal source of progesterone during the oestrous cycle and early pregnancy of red deer (Adam et al., 1985). As predicted, administration of the prostaglandin analogue, cloprostenol, on day 15 of luteal development resulted in a marked reduction of progesterone secretion within 2 days, indicating rapid demise of the corpora lutea. However, the efficacy of cloprostenol in inducing luteal regression in red deer has not been evaluated in detail. In the present trial, the return to oestrus after cloprostenol administration occurred over 7 days and two superovulated hinds retained twin embryos to term (i.e. about 230 days from removal of CIDR devices) even though plasma progesterone concentrations declined in these individuals. Furthermore, in a more recent trial on oestrous synchronization of red deer $(\mathrm{G}$. W. Asher, unpublished), about $30 \%$ of hinds treated with cloprostenol on day 14 following mating to fertile stags failed to reject their embryos. There are several considerations about these observations. First, failure of complete luteolysis of multiple corpora lutea may occur if there is a heterologous age structure within the luteal population, whereby younger corpora lutea are refractory to prostaglandins (i.e. the corpus luteum is known to be refractory to prostaglandins before day 11 in wapiti, Cervus elaphus nelsoni (Glover, 1985). Second, the presence of the preimplantation embryo(s) may confer a degree of refractoriness of corpora lutea to prostaglandins in this species. Third, it is possible that preimplantation embryos are not as sensitive to reduced progesterone concentrations as in other domestic species and may be retained in vivo in a viable state. Further elucidation of the efficacy of prostaglandins is important for embryo transfer programmes as it may be detrimental for red deer donors to retain multiple embryos that are not recovered during flushing.

We thank M. Bertram for veterinary assistance during this study and numerous staff from the Reproduction Group, Ruakura Agricultural Centre, for assistance with animal handling and behavioural observations. J. G. E. Thompson and H. R. Tervit have provided valuable advice throughout the course of this study. 


\section{References}

Adam, C.L., Moir, C.E. \& Atkinson, T. (1985) Plasma concentration of progesterone in female red deer (Cervus elaphus) during the breeding season, pregnancy and anoestrus. Journal of Reproduction and Fertility 74, 631-636.

Asher, G.W. (1985) Oestrous cycle and breeding season of farmed fallow deer, Dama dama. Journal of Reproduction and Fertility 75, 521-529.

Asher, G.W. (1990) Effect of subcutaneous melatonin implants on the seasonal attainment of puberty in female red deer (Cervus elaphus). Animal Reproduction Science 22, 145-159.

Asher, G.W. \& Thompson, J.G.E. (1989) Plasma progesterone and $\mathrm{LH}$ concentrations during oestrous synchronization in female fallow deer (Dama dama). Animal Reproduction Science 19, 143-153.

Asher, G.W., Barrell, G.K. \& Peterson, A.J. (1986) Hormonal changes around oestrus of farmed fallow deer, Dama dama. Journal of Reproduction and Fertility 78, 487-496.

Asher, G.W., Adam, J.L., Otway, W., Bowmar, P., van Reenan, G., Mackintosh, C.G. \& Dratch, P. (1988a) Hybridization of Père David's deer (Elaphurus davidianus) and red deer (Cervus elaphus) by artificial insemination. Journal of Zoology (London) 215, 197-203.

Asher, G.W., Adam, J.L., James, R.W. \& Barnes, D. (1988b) Artificial insemination of farmed fallow deer (Dama dama): fixed time insemination at a synchronized oestrus. Animal Production 47, 487-492.

Asher, G.W., Peterson, A.J. \& Duganzich, D. (1989) Adrenal and ovarian sources of progesterone secretion in young female fallow deer, Dama dama. Journal of Reproduction and Fertility 85, 667-675.

Asher, G.W., Kraemer, D.C., Magyar, S.J., Brunner, M., Moerbe, R. \& Giaquinto, M. (1990a) Intrauterine insemination of farmed fallow deer (Dama dama) with frozen-thawed semen via laparoscopy. Theriogenology 34, 569-577.

Asher, G.W., Fisher, M.W., Smith, J.F., Jabbour, H.N. \& Morrow, C.J. (1990b) Temporal relationship between the onset of oestrus, the preovulatory LH surge and ovulation in farmed fallow deer, Dama dama. Journal of Reproduction and Fertility 89, 761-767.

Asher, G.W., Jabbour, H.N., Berg, D., Fisher, M.W., Fennessy, P.F.\& Morrow, C.J. (1991) Artificial insemination, embryo transfer and gamete manipulation of farmed red deer and fallow deer. Proceedings of $a$ Deer Course for Veterinarians, Deer Branch NZVA, Course No. 8 pp. $275-306$. New Zealand Veterinary Association, Wellington.

Cumming, I.A., Buckmaster, J.M., Blockey, M.A. deB., Goding, J.R., Winfield, C.G. \& Baxter, R.W. (1973) Constancy of interval between luteinizing hormone release and ovulation in the ewe. Biology of Reproduction 9, 24-29.

Fennessy, P.F., Fisher, M.W., Shackell, G.H. \& Mackintosh, C.G. (1989a) Superovulation and embryo recovery in red deer (Cervus elaphus) hinds. Theriogenology 32, 877-883.

Fennessy, P.F., Fisher, M.W. \& Asher, G.W. (1989b) Synchronisation of the oestrous cycle in deer. Proceedings of a Deer Course for Veterinarians, Deer Branch
(NZVA) Course No. 6 pp. 29-35. New Zealand Veterinary Association, Wellington.

Fennessy, P.F., Mackintosh, C.G. \& Shackell, G.H. (1990a) Artificial insemination of farmed red deer (Cervus elaphus). Animal Production 51, 613-621.

Fennessy, P.F., Moore, G.H. \& Littlejohn, R.P. (1990b) Hormonal induction of twinning in farmed red deer (Cervus elaphus): comparative mortality and growth of twins and singles to weaning. Animal Production 51, $623-630$

Fisher, M.W., Fennessy, P.F., Suttie, J.M., Corson, I.D., Pearse, A.J.T., Davis, G.H. \& Johnstone, P.D. (1986) Early induction of ovulation in yearling red deer hinds. Proceedings of the New Zealand Society of Animal Production 46, 171-173.

Fisher, M.W., Fennessy, P.F. \& Davis, G.H. (1989) A note on the induction of ovulation in lactating red deer hinds prior to the breeding season. Animal Production 49, 134-138.

Glover, G.J. (1985) Aspects of Reproductive Physiology of Female Wapiti. MSc Thesis, University of Saskatchewan.

Guinness, F.E., Lincoln, G.A. \& Short, R.V. (1971) The reproductive cycle of the female red deer, Cervus elaphus L. Journal of Reproduction and Fertility 27, $427-438$.

Henricks, D.M., Dickey, J.F. \& Niswender, G.D. (1970) Serum luteinizing hormone and plasma progesterone levels during the estrous cycle and early pregnancy in cows. Biology of Reproduction 2, 346-351.

Hunter, M.G. \& Southee, J.A. (1989) Heterogeneity in the luteal population following superovulation with pregnant mare serum gonadotrophin and human chorionic gonadotrophin in the sheep. Journal of Endocrinology 121, 459-465.

Jabbour, H.N., Asher, G.W., Thompson, J.G.E., Tervit, H.R. \& Morrow, C.J. (1990) Studies on superovulation and embryo recovery in farmed red and fallow deer. In Biology of Deer, p. 357. Ed. R. D. Brown. Springer-Verlag, NY.

Jabbour, H.N., Veldhuizen, F.A., Green, G., Langridge, M. \& Asher, G.W. (1991) Fertility of fallow deer (Dama dama) does following synchronisation of oestrus with CIDR devices or prostaglandin. Proceedings of the New Zealand Society of Animal Production 51, 147-155.

Jopson, N.B., Fisher, M.W. \& Suttie, J.M. (1990) Endogenous and exogenous progesterone in red deer hinds. Animal Reproduction Science 23, 61-73.

Kelly, R.W., McNatty, K.P., Moore, G.H., Ross, D. \& Gibb, M. (1982) Plasma concentrations of LH, prolactin, oestradiol and progesterone in female red deer (Cervus elaphus) during pregnancy. Journal of Reproduction and Fertility 64, 475-483.

Mori, Y. \& Kano, Y. (1984) Changes in plasma concentrations of $\mathrm{LH}$, progesterone and oestradiol in relation to the occurrence of luteolysis, oestrus and time of ovulation in the Shiba goat (Capra hircus). Journal of Reproduction and Fertility 72, 223-230.

Nancarrow, C.D., Murray, J.D., Boland, M.P., Sutton, R. \& Hazelton, I.G. (1984) Effect of gonadotrophin releasing hormone in the production of single-cell 
embryos for pronuclear injection of foreign genes. In Reproduction in Sheep, pp. 286-288. Eds D. R. Lindsay \& D. T. Pearce. Australian Academy of Science, Canberra.

Quirke, J.F., Hanrahan, J.P. \& Gosling, J.P. (1981) Duration of oestrus, ovulation rate, time of ovulation and plasma LH, total oestrogen and progesterone in Galway adult ewes and ewe lambs. Journal of Reproduction and Fertility 61, 265-272.

Robinson, T.J., Scaramuzzi, R.J. \& Smith, C.A. (1987) The time of mating and of $\mathrm{LH}$ release and subsequent fertility of anoestrous Border Leicester $\times$ Merino ewes treated with progestagen and pregnant mare serum gonadotrophin. Animal Reproduction Science 13, 23-26.

Scaramuzzi, R.J., Caldwell, B.V. \& Moor, R.M. (1970) Radioimmunoassay of $\mathrm{LH}$ and estrogen during the estrous cycle of the ewe. Biology of Reproduction 3, 110-119.

Schams, D., Schallenberger, E., Hoffmann, B. \& Karg, H. (1977) The oestrous cycle of the cow: hormonal parameters and time relationships concerning oestrus, ovulation and electrical resistance of the vaginal mucus. Acta Endocrinologica 86, 180-192.

Thompson, J.G.E. \& Smith, J.F. (1988) Effect of nutrition on the ovulatory response of Coopworth ewes to varying doses of two FSH preparations. Proceedings of the New Zealand Society of Animal Production 48, 81-85.

Thompson, J.G.E., Simpson, A.C., James, R.W. \& Tervit, H.R. (1990) The application of progesteronecontaining CIDR devices to superovulated ewes. Theriogenology 33, 1297-1304.

Walker, S.K., Smith, D.H. \& Seamark, R.F. (1986) Timing of multiple ovulations in the ewe after treatment with FSH or PMSG with and without GnRH. Journal of Reproduction and Fertility 77, 135-142.

Walker, S.K., Smith, D.H., Seamark, R.F. \& Godfrey, B. (1987) Variation in the timing of multiple ovulations following gonadotrophin releasing hormone treatment and its relevance to collecting pronuclear embryos of sheep. Theriogenology 28, 129-137.

Received 19 August 1991 